\title{
Una aproximación a la dramaturgia de Javier Berger y su obra Franco, el retorno
}

Juan Antonio Bernal Tena

\section{(2) OpenEdition}

\section{Journals}

Edición electrónica

URL: https://journals.openedition.org/cher/1126

DOI: $10.4000 /$ cher. 1126

ISSN: 2803-5992

Editor

Presses universitaires de Strasbourg

Edición impresa

Fecha de publicación: 11 julio 2019

Paginación: 115-128

ISBN: 979-10-344-0046-1

ISSN: 1968-035X

\section{Referencia electrónica}

Juan Antonio Bernal Tena, «Una aproximación a la dramaturgia de Javier Berger y su obra Franco, el retorno", reCHERches [En línea], 22 | 2019, Publicado el 05 octubre 2021, consultado el 17 noviembre 2021. URL: http://journals.openedition.org/cher/1126 ; DOI: https://doi.org/10.4000/cher.1126 


\title{
Una aproximación a la dramaturgia de Javier Berger y su obra Franco, el retorno
}

\author{
Juan Antonio Bernal Tena' ${ }^{1}$
}

$\int \mathrm{a}$ avier Berger Díaz nace en Sevilla en 1973, pero pasa su infancia en Marbella. Comienza con el teatro universitario en Granada (1991-1995) realizando sus primeras obras de pequeño formato y de allí pasa a Sevilla a estudiar en el tristemente desaparecido Instituto del Teatro de Sevilla. Posteriormente realiza un máster de guion de cine y televisión en Madrid.

Como dramaturgo ha cosechado multitud de premios, siendo el primero en recibir el premio Romero Esteo con su obra Doctor, ¿Es cierto que el hombre se compone de un 70\% de agua?, iniciando así una generación denominada con el mismo nombre. Esta generación Romero Esteo aunque de estilos y contenidos muy diferentes, poseían valores "herederos del teatro de Sarah Kane, impulsora de un teatro provocador y visceral dirigido a los sentidos, al subconsciente de las personas" (Monago 1999: 15).

De entre los premios que Berger ha recibido cabe destacar, el Premio Gemma Teatro (1996), Premio Romero Esteo (1997), Mención especial Romero Esteo (1998), Premio Teatro Joven de Sevilla (2005), Premio Rafael Guerrero (2000 y 2008), Premio Animatur-sur (2011), Accésit Jarra Azul (2011).

Su producción dramática hasta la fecha es muy extensa predominando en sus textos la comedia y utilizando un humor negro que lo define y que le permite expresar multitud de temas y moverse por cualquier registro sin ningún tipo de encorsetamientos, con total libertad:

Desde las primeras a sus últimas obras se percibe una clara evolución desde formulaciones más explosivas y, hasta cierto punto, provocativas tanto en contenido como en forma hasta un cuidado mayor en la exposición y en la estructura dramática (Ministerio Educación, cultura y deporte 2018).

En cuanto al estilo podemos decir que todas sus obras giran en torno a la soledad, el desasosiego, la pereza y la búsqueda, pero desde un punto de vista cómico y utilizando su obra para hacer crítica social, con un lenguaje cercano al

1 Juan Antonio Bernal Tena, Departamento de Dirección y Plástica Teatral - Escuela Superior de Arte Dramático de Córdoba, España. 
público. Su intención no es provocar, pero "en la esencia de la comedia está el enfrentamiento, la anarquía o el sentimiento ácrata de la vida” (Berger 2018). En todas sus obras hay un elemento cómico o el intento de diálogos ingeniosos que se repiten de manera recurrente. Aunque en los últimos años se está decantando por el drama con obras como La Felicidad es el deseo de repetir (2018).

El proceso creativo de Berger surge o bien a través de un encargo, la idea ya está dada, o de una "maleta" donde va acumulando papelitos con frases, imágenes, posibles escenas, elementos que le inspiran. En los últimos tiempos usa de manera recurrente tramas maestras clásicas y a partir de ahí imagina cómo sería esa historia si ocurriese hoy en día. Este proceso para Javier es puro entretenimiento.

De entre todas sus obras, de la que se siente más orgulloso, quizás sea Se acabó la comedia (2011), una relectura contemporánea de Macbeth de Shakespeare, cuya trama transcurre en un bar. Esta obra a fecha de hoy sigue sin estrenarse, pero sí está publicada. Una obra honesta y cargada de emoción según Berger. De entre las que más le costó escribir podríamos decir que el autor considera que son las obras que se quedan en el cajón, obras fallidas que nunca ven la luz, para Berger, las obras muertas.

Si hiciéramos una clasificación de su obra podríamos clasificarla en piezas largas ${ }^{2}$ que según el autor algunas están completas y otras "solo hay fragmentos, porque vivimos tiempos de consumo rápidos, píldoras pequeñas y relaciones líquidas" (Berger 2018). Entre ellas están: Doctor, ¿es cierto que el hombre se compone de un 70\% de agua?; Elena y el fenómeno Bórbely; El sexo de los títeres; Franco, el retorno; La increíble historia aleatoria del hombre-muro; Lope a lo-petit; Operación Encarni; Poderosos caballeros; Se acabó la comedia; UVI, zona cero (coautor); Veni, Vidi, vinci; La Felicidad es el deseo de repetir.

Dentro de sus obras breves ${ }^{3}$ tenemos: Lester; Culto a la Abundancia; Comic Love; Emergencia Zombie; Gran Calibre; Hasta donde yo sé pudo ser Elvis; Homenaje a Bécquer, digo a Beckett; La pasión de Johann y Sebastian (coautor); La voz del concejal; Perro y coneja; Políticamente incorrecto (coautor); Romeo \& Julieta Airlines; Tabacoooo!!!; Todo en casa sabe mejor.

Actualmente está embarcado en una revisión muy libre de Las tres hermanas, de Chejov, para tres actores. Y el estreno de un experimento escénico dirigido por Elena Bolaños y protagonizado por Raquel Madrid, a partir de su texto $\mathrm{La}$ Felicidad es el deseo de repetir (2018).

La mayoría de sus obras han obtenido aplausos del público y la crítica. En todas ellas destaca un humor tintado de inteligencia que no deja de exprimir carcajadas desde el primer segundo. Consideradas como obras deliciosas y diferentes, las obras de Berger siempre han sido representadas por compañías pequeñas, como Los Primos de Píter, de las que, según la crítica, se valora

2 Obras de teatro cuya representación dura como mínimo hora y cuarto.

3 Piezas que no exceden los 30 minutos de duración, aunque la mayoría, según el autor, andan por los 10 ó 15 minutos. 
especialmente la calidad interpretativa. Es el caso de Franco, el retorno que fue considerada como una apuesta atrevida, divertida de dos viejitos encantadores, Paco y Carmen, que bien pudieron ser Francisco Franco y Carmen Polo. Una comedia que, según Lara Martínez para $\mathrm{ABC}$, "no parodia, pues no imita al personaje desde arriba, sino que le mira de frente como ya hacían los bufones ante el rey" (Martínez 2010: 110).

Según Berger (2018), Franco, el retorno es una historia de dos viejitos encantadores, aunque enfermizamente nostálgicos. Una espera en el dormitorio de Carmen y Paco. Un dormitorio austero por el que pasarán los fantasmas de la vida del dictador. Una obra, que su autor define como, de barrio, pequeña, de dormitorio, de mesita de noche, de tradiciones católicas y karaokes japoneses de la mano. Estructurada en base a cuadros de los distintos momentos de la vida del caudillo. Una farsa llena de cuchillos cargados de la necesidad de reírnos hasta de nuestra sombra. Un viaje por la biografía de uno de los personajes más trascendentales, queramos o no, del siglo XX en España. Desde el punto de vista menos documentado, más frívolo, más divertido y claro, más espectacular.

En el breve espacio para este artículo no cabe, por supuesto, el planteamiento riguroso y pormenorizado de la puesta en escena; ni tan siquiera su explicación detallada. Nos limitaremos, pues, a insinuar algunas de las ideas, algunos de los momentos, algunas de las características de la obra, que parten de nuestra experiencia propia en el montaje de la obra y la relación con el autor.

El espectáculo Franco, el retorno (2009) fue una producción de la compañía sevillana Los Primos de Píter, que se estrenó el 11 de febrero de 2010 y cuya duración fue de 70 minutos. El equipo técnico y artístico se nos presenta en el Dramatis personae mediante una descripción a tono con el lenguaje de la obra ${ }^{4}$ :

BANDO NACIONAL:

Paco: Juan Antonio Bernal

Carmen: Manuela Luna

Servidor: Feliú Cervi

BANDO REPUBLICANO:

Texto y Dirección: Javier Berger

Iluminación: Pedro Domínguez

Música y Sonido: Daniel Abad

Asesoramiento Vocal: Manolo Asensio

Escenografía/Atrezzo: Los Primos de Píter

Títeres: Feliú Cervi

Vestuario: Mai Canto

Maquillaje: Juan Espinosa

Fotografía: Carlos Feliú

Diseño Gráfico: Juan Antonio Bernal (Los Primos de Píter 2010)

4 Los datos reflejados en cuanto a equipo artístico y técnico del programa de mano, así como galería fotográfica, dossier del espectáculo y ficha técnica del mismo se encuentran disponibles en la página web de la compañía: https://losprimosdepiter. jimdo.com 
Fue en julio de 2009 cuando la Cía. Los Primos de Píter decide embarcarse en un nuevo montaje y dar el salto al teatro de adultos, ya que llevaba tiempo haciendo teatro infantil. La compañía quería montar una comedia debido a su marcado carácter cómico, y el destino puso en su camino a Javier Berger. Conocíamos parte de la obra del autor, pero no Franco, el retorno.

En esos momentos Javier como dramaturgo y director de escena se sentía atraído por el personaje de Francisco Franco "desde siempre, como dictador, por esa capacidad que tuvieron él como otros dictadores para convencer a tanta gente" (Bernal Tena 2018a). Eligió a Franco porque protagonizó cuarenta años de la historia de España en un momento en que parecía bastante superado el franquismo. Estas razones fueron las que lo motivaron a escribir este texto, por una obsesión personal del autor por los dictadores, aunque, según Berger, la insistencia de un amigo que insistía cada vez que lo veía y le decía "Franco, el musical. Eso es un éxito" (Ídem). Y como "la comedia no está al servicio de nadie. No tiene ni Dios ni patria ni ley. Por eso, es hora de 'Franco, el retorno'. Es hora de reírnos de nuestra historia y de nosotros. Un pueblo que no se ríe de su historia está condenado a ser aburrido" (Martínez 2010: 110).

Era la época en la que había llegado a la Gran Vía de Madrid la locura de los musicales. Además, ya existía en Londres un musical sobre Margaret Thatcher. Y fue cuando Los primos de Píter nos pusimos en contacto con Javier Berger y le dimos el empujón que necesitaba para terminar la obra. Se modificó la idea, ya que "no iba a ser un montaje para Gran Vía, sino enfocado para salas de mediano formato” (Bernal Tena 2018a) y en una época en la que difícilmente se podría mostrar este tipo de obra si no fuese por las salas alternativas de Sevilla, independientes de los teatros públicos. Una época en la que la programación de estos espacios dio cabida a un mayor tipo de obras.

Contar en esa época con autores de la talla de Javier Berger era, por su trayectoria, un reclamo para quien quisiera saber lo que se estaba cocinando en el teatro sevillano de la época.

Por otro lado, autores como Javier Berger abrieron la brecha en estas salas sevillanas, sacudiendo la escena con textos como Franco, el retorno. Un texto cuyo planteamiento original era el siguiente: dos viejecitos que rememoran la historia del dictador, y que nunca sabemos si son ellos mismos o una pareja de dos nostálgicos franquistas. Todo ello enmarcado en el karaoke, que es el musical del proletariado.

Cuando montamos la obra parecía que el tema de Franco era un tema viejo, sin interés $y$, sin embargo, a fecha de hoy, por desgracia, sigue de completa actualidad ${ }^{5}$; de hecho, incluso puede ser que tenga más sentido. En su momento, Javier quiso plasmar que "la figura del dictador seguía presente, que extendía su mano sobre la democracia y sobre todo convertirlo en una sátira del poder, de

5 Valgan de ejemplo los últimos acontecimientos con respecto a la exhumación de los restos de Franco del Valle de los Caídos, o el que la Ley de Memoria Histórica no se cumpla. 
la religión y de las miserias humanas calzoncilleras y de misa diaria en este país [España]" (Ibídem).

La corriente artística que inspiró al autor para esta obra podría estar cerca a Kantor, aunque probablemente también estuviese más cerca de "la verbena, los títeres de cachiporra y el karaoke de borrachos" (Ibídem). Realmente la obra está inspirada en el teatro de Arrabal, del que Javier es un auténtico apasionado. La obra se caracteriza por un humor absurdo, ofrece una visión crítica y utiliza tanto signos no verbales como personajes simbólicos, entre otros.

Dentro del enfoque semiótico había una intención de ensoñación, de limbo, de castigo eterno a un dictador que tendría que repetir por siempre su historia, aunque la repetición se va malversando y alejando de los hechos. Y para ello utilizamos unos signos visuales y acústicos que se manifestaron en la obra a través de ciertas imágenes como:

- El dormitorio como isla.

- El limbo de Sísifo.

- El friteo de un viejo gramófono.

- La austeridad cuartelera.

- La falsa representación de los milagros.

- La merluza hervida.

- El celibato como falsa virtud.

La reconstrucción arqueológica de la obra para Javier fue un proceso bastante clásico, comenzando por la documentación, un par de biografías, algunos documentales y sobre todo un libro llamado La vida intima de Adolfy Eva, sobre la vida de Hitler y Eva Braun, el cual le da la idea del posible punto de vista para el texto de su obra Franco, el retorno. Posteriormente, buscó una estructura que le sirviera, en este caso sería cronológica y circular. Todo el proceso le llevó a escribir la obra, periodo en el que invirtió siete meses aproximadamente.

Para revisar la memoria histórica, Berger recurre a pilares reales y datos comprobados para crear una ficción, "un lugar irreal, aunque esté plagado de guiños auténticos. Los espectadores que conocen la historia descubrirán los datos originales y los que he inventado, algunos inspirados en rumores, donde fantaseo sobre lo que hacían Paco y Carmen en la intimidad" (Martínez 2010: 110). Una puesta en escena que el autor considera como una farsa simbolista pseudohistórica y en la que hay una progresión lineal en la reconstrucción histórica que se mezcla con las propias obsesiones del protagonista y acaba convirtiéndose en una historia cíclica. Una historia en la que predomina el concepto del amor del dictador y cómo antepone su carrera profesional al amor hacia Carmen.

Fue así como Javier Berger concibió Franco, el retorno, como una obra que cuenta la historia de dos viejos encantadores, aunque enfermizamente nostálgicos. Es una espera en el dormitorio de Carmen y Paco. Un dormitorio austero por el que pasan todos los fantasmas de la vida del dictador. Y para avivar su arruinada vida sexual, juegan a recrear la vida del caudillo (Berger 2009). "La vida de dormitorio del dictador, su relación con Carmen es lo que 
más se desconoce", comenta Javier Berger (Bernal Tena 2018a). Con sentido del humor y algún que otro tema musical, se presenta una pareja a la que le queda poco tiempo de vida, y por eso mismo se ocupa en hacer una revisión de su pasado.

Haciendo un análisis psicológico de la obra podríamos decir que se quiere transmitir la decadencia y cómo uno reescribe su propia historia al pasar el tiempo para salir bien parado. La obra se podría resumir en lo que le pregunta Paco a Carmen: “Carmen, ¿lo hice bien?”. Carmen sabe que no, pero le contesta: "Sí, Paco" (Ídem.)

A nivel plástico e interpretativo, el planteamiento inicial que surge al abordar esta obra fue la idea de "el juego" como punto de partida. José Luis Feliú nos comenta:

[la obra] es un continuo juego del personaje por rememorar todos los puntos más álgidos de su vida. La idea principal que enlazaría todo a nivel plástico y argumental sería, pues, el juego. Recrear un espacio lúdico que permitiera a los actores jugar con los personajes y a los personajes jugar con la escenografía, de tal manera que la escenografía jugara con el espacio, y este con los actores. Es por lo que recreamos entonces, una habitación: el dormitorio personal y privado de Franco y Carmen. Si bien hubo cambios en los detalles, la idea de espacio original se mantuvo durante todo el proceso de montaje. Teníamos claro que si Franco jugase, sería en su habitación. Entre todos los juguetes, estaban los títeres, elementos perfectos para jugar a ser otro, desdoblar personalidad y confundir identidades (Bernal Tena 2018b).

La obra comienza reconociendo a un personaje, Franco, junto a la mesilla de noche de su habitación. Dos camas al fondo y la lámpara terminan de recrear el dormitorio del matrimonio. Esa habitación debía desaparecer con el transcurso del espectáculo. Romper sus paredes y transportar al público cada vez más allá de sus límites, hacerle olvidar la idea de cama y mesillas como tales; para solo al final, después del viaje, volver a la realidad del dormitorio. El espacio escénico, pues, sugiere ese dormitorio como representación de una isla en la que vive esta pareja totalmente alejados del mundo y sin relación con él. Así quedaba justificado el problema del tiempo. Para transmitir a través de la propuesta plástica determinados sentimientos y emociones que los personajes vivían en escena había que llevar al público, a través de los cambios escenográficos, de viaje por la vida del personaje, para al final, estrellarlo en su realidad.

A nivel estructural, la escenografía estaba dividida en tres grupos definidos por su función:

a) Elementos delimitadores del espacio. Un marco rojo en el suelo (7 x $4 \mathrm{~m}$. aproximadamente) para marcar la "habitación", la zona de juego de los actores (dentro personaje, fuera actor). Y una lámpara en el centro de la "habitación" para marcar la altura digna de un gran dormitorio.

b) Elementos propios del dormitorio. Dos camas y una mesilla de noche. Las posiciones y movimientos de estos elementos determinarían el ambiente lúdico en el que se recreaban los personajes. Cada escena, cada historia, cada conflicto, tenía su distribución particular. 
c) Títeres. Los títeres como parte del juego, siendo juguetes y personajes a la vez. Entraban y salían de la habitación como juguetes que entran y salen de un armario, dando una distancia a las recreaciones de la vida del personaje y dándole un toque infantil a un tema nada amable. Se usaron alrededor de cinco o seis títeres.

Si bien el desarrollo de la obra era lineal, las historias que contaban los personajes iban en desorden cronológico, apoyando y ambientando a dichas historias la escenografía. Cada elemento dejaba de ser él mismo para tomar una identidad ajena: así una cama, fue cama de dormitorio, cama de hospital, barricada, cárcel y muro. Los mismos personajes eran los que despojaban a los elementos de su función natural para integrarlos a su mundo onírico. Ningún elemento alteraba su forma original, simplemente se jugaba con ellos. Igual que un niño pequeño usa una escoba para cabalgar.

Aunque los actores en ese momento no conocíamos a Berger, el escenógrafo sí lo conocía de hacía años, tanto a él como su forma de trabajar. El proceso de trabajo fue muy cómodo. Desde el principio aceptó las propuestas, tanto de interpretación como escenográficas que planteó el grupo, e incluso modificando sobre la marcha el texto y reescribiendo in situ algunas de las escenas que, por diversos motivos, en esos momentos no funcionaron. Todos nos adaptamos fácilmente al intercambio de ideas.

Con respecto a la propuesta escenográfica, el mismo guión dejaba muy claro dónde sucedían los hechos. Quisimos ser fiel al texto en este aspecto. Con respecto a los detalles, Javier siempre dio carta blanca para hacer cualquier propuesta, tanto en escenografía como en vestuario, maquillaje y peluquería. En esos campos, delegó y confió totalmente en el grupo.

Nuestra experiencia como actores de la obra nos supuso una manera distinta de trabajar hasta el momento. Partiendo de la misma idea de juego, "buscamos los personajes desde el externo, es decir, un trabajo realizado de fuera a dentro, observando, copiando gestos e imitando tanto discursos del dictador como de su esposa" (Bernal Tena 2018c). Intentamos primero acercarnos a los personajes históricos, creando una máscara, una manera de hablar, de andar, unas pausas; para después dotarlos de la verdad. Así encontramos a nuestro Paco (Francisco Franco) y a nuestra Carmen (Carmen Polo), unos personajes que tendían a lo farsesco. El proceso de investigación de los personajes fue laborioso, documentándonos tanto en archivos, hemerotecas, etc. y, sobre todo, apoyándonos en fuentes historiográficas, así como en discursos reales del dictador.

Aunque en el texto original aparecían solo dos personajes, Berger decidió incorporar un tercero, que no hablaba, el Servidor, para apoyar en escena a los personajes principales. El Servidor hacía tanto de mayordomo, como de atrezzista, moviendo todo el mobiliario para recrear distintos ambientes y manteniendo un discurso interno con Carmen y Franco. De la misma manera, estaba a cargo de los títeres, desdoblando los personajes que Franco recordaba y, sobre todo, inventaba. Era un personaje cómodo de representar: 
El peso de la obra lo llevaba el matrimonio, y los movimientos en escena estaban tan marcados que eran fáciles de recordar. El personaje es una mezcla de algunos extras de la vida de Franco: un mayordomo, un militar, un republicano, un monaguillo y un médico experimental. Cada uno de ellos presentados dentro y fuera del juego planteado por el matrimonio (Bernal Tena 2018b).

Quizás la mayor dificultad de los personajes estaba en los momentos musicales. No éramos unos virtuosos del canto, así, la dificultad no radicaba en cantar bien o mal, si no en no perder la concentración y fuerza del personaje por tratar de cantar mejor.

Para Javier Berger el proceso de trabajo depende de cada obra. En sus inicios, se apoyaba mucho en su instinto, pero a medida que aprendió el oficio, comenzó a estructurar y sistematizar el proceso, y aprendió a acotar los tiempos de "escribir por escribir". Aun así, de vez en cuando se sale del proceso habitual de premisa, sinopsis, argumento y se acerca de una forma menos dogmática a los temas que quiere tratar en su obra. Usa imágenes, músicas y escritura automática ${ }^{6}$.

Con respecto al método de trabajo para la puesta en escena, la obra se montó en un mes y medio aproximadamente. La primera toma de contacto fueron una serie de reuniones donde nos dio a conocer el texto e hicimos las primeras lecturas. El trabajo con Javier Berger como director fue siempre fluido y muy distendido ya que permitía y recogía cualquier aportación que le diésemos, tanto ideas como nuevos enfoques. El texto estuvo definido desde el principio, pero fue sufriendo cambios y pequeñas modificaciones que se fueron realizando a lo largo del proceso de trabajo. Para eso Javier es muy generoso y evita que el texto se encorsete, tanto es así que incluso el título original de la obra, Franco, Greatest Hits (El musical), fue reemplazado durante el montaje por Franco, el retorno.

En la obra no había acotaciones, y en el montaje se decidió estructurarla en escenas, con unos títulos inventados por el autor. También decidimos incorporar una serie de temas musicales ${ }^{7}$.

A modo de conclusión hay que decir que la obra no tuvo la repercusión que todos esperábamos y que nos hubiese gustado. Javier Berger incluso llegó a dudar de la conveniencia de dirigir sus propios textos. Nos confesó que, si la volviésemos a montar hoy día, lo haría de forma más directa, más canalla y mucho más provocadora, un poco más decadente, y quizás situándola en el Valle de los Caídos, en la basílica donde está enterrado el dictador (Bernal Tena 2018a)

Aparte de un par de cartas de franquistas indignados, la obra no levantó mucha polvareda. Seguramente, hoy en día, tendría mucha más repercusión.

6 Véase anexo I. Algunas imágenes del cuaderno de dirección elaborado junto a José Luis Feliú Cervi, escenógrafo de la obra.

7 Véase anexo III. Cuadro estructura obra Franco el retorno y listado de temas musicales utilizados para la obra. 


\section{Bibliografía}

Berger, J. (2018), Javier Berger dramaturgo y actor, <https://javierberger.com/ obras/>.

Bernal Tena, J. A., (2018a), “Entrevista a Javier Berger”, 15/05/2018, Sevilla. Bernal Tena, J. A., (2018b), "Entrevista a José Luis Feliú”, 20/06/2018, Sevilla. Bernal Tena, J. A., (2018c) "Entrevista a Luna Manuela”, 21/06/2018, Sevilla. Los primos de Píter, (2010), FRANCO, el retorno, <https://losprimosdepiter. jimdo.com/p\%C3\%A1gina-principal/teatro-adulto/franco-el-retorno/>.

Martínez, L. (2010), Javier Berger en el dormitorio con Franco, ABC,19/02/2010 Ministerio de Educación, cultura y deporte (2018), Buscautores. Javier Berger: Biografía, <http://buscautores.aat.es/wp-content/uploads/javier-berger.pdf $>$. Monago, T. (1999), Teatro de emociones, Diario de Sevilla, 17/03/1999.

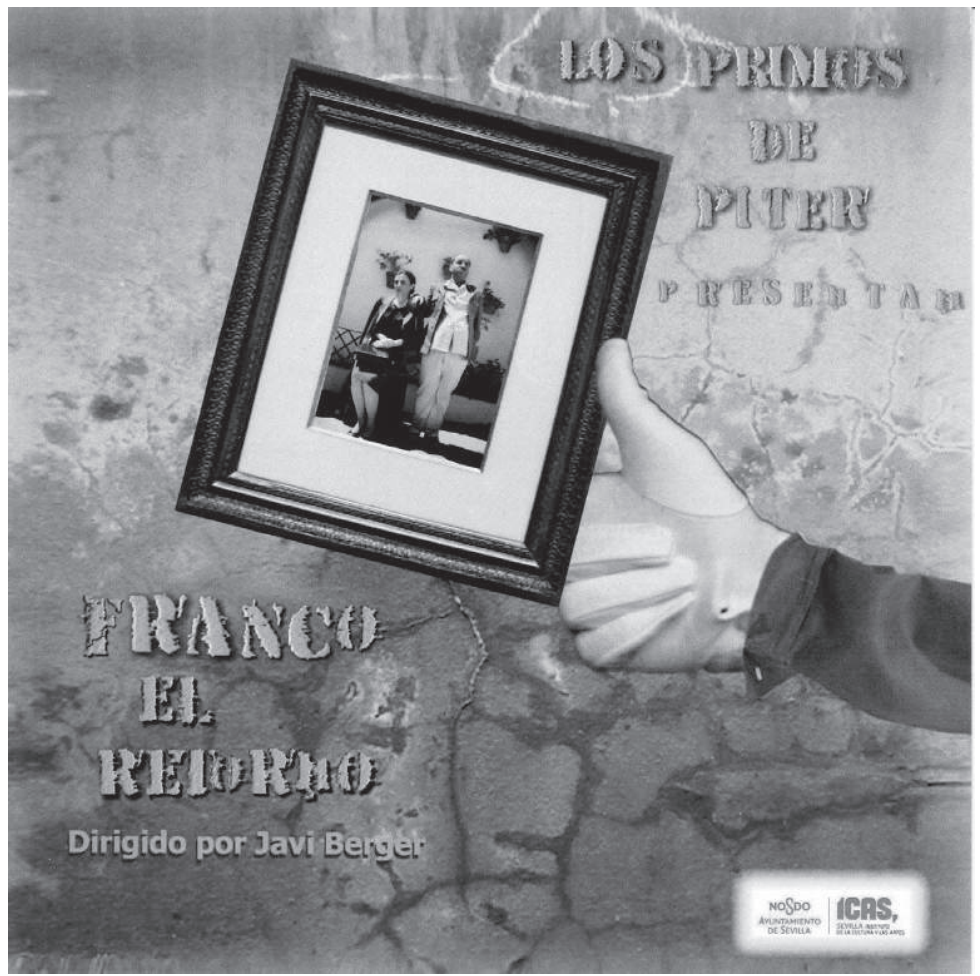

Cartel del espectáculo Franco, el retorno de Javier Berger. Diseño gráfico Juan Antonio Bernal. (c) Juan Antonio Bernal. 
ANEXO I. Imágenes del cuaderno de dirección de la obra Franco, el retorno.

\section{Cuaderno de dirección}

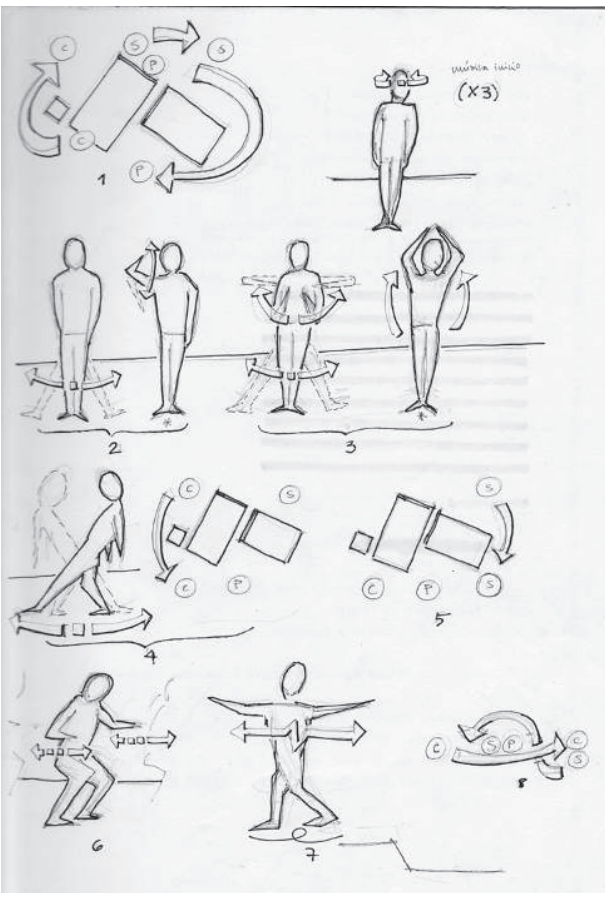

Cuaderno de dirección

C José Luis Feliú Cervi.

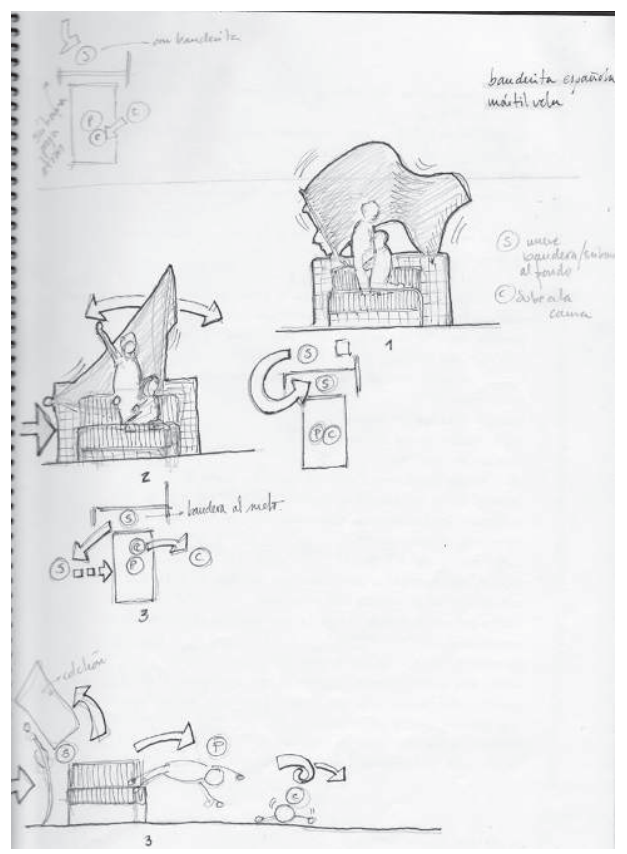

Escena "El barco"

Paco deja de cantar y se sube a la cama como si fuera un barco.

Carmen sube a la cama

(c) José Luis Feliú Cervi. 


\section{Masturbación}

Baja sus pantalones, muestra su miembro anillado a Santa Teresa.

\section{PACO:}

Oh, Teresa...

Vivo sin vivir en mí, $y$ de tal manera espero, que muero porque no muero. Porque si es dulce el amor, no lo es la esperanza larga, porque muriendo, el vivir me asegura mi esperanza. Muero ya, el vivir se alcanza, no tardes, que te espero, que muero porque no muero. Sí, sí, síiiii, mueroooo. (c) José Luis Feliú Cervi.

\section{Coreografía}

"Moderno pero español" (C) José Luis Feliú Cervi.
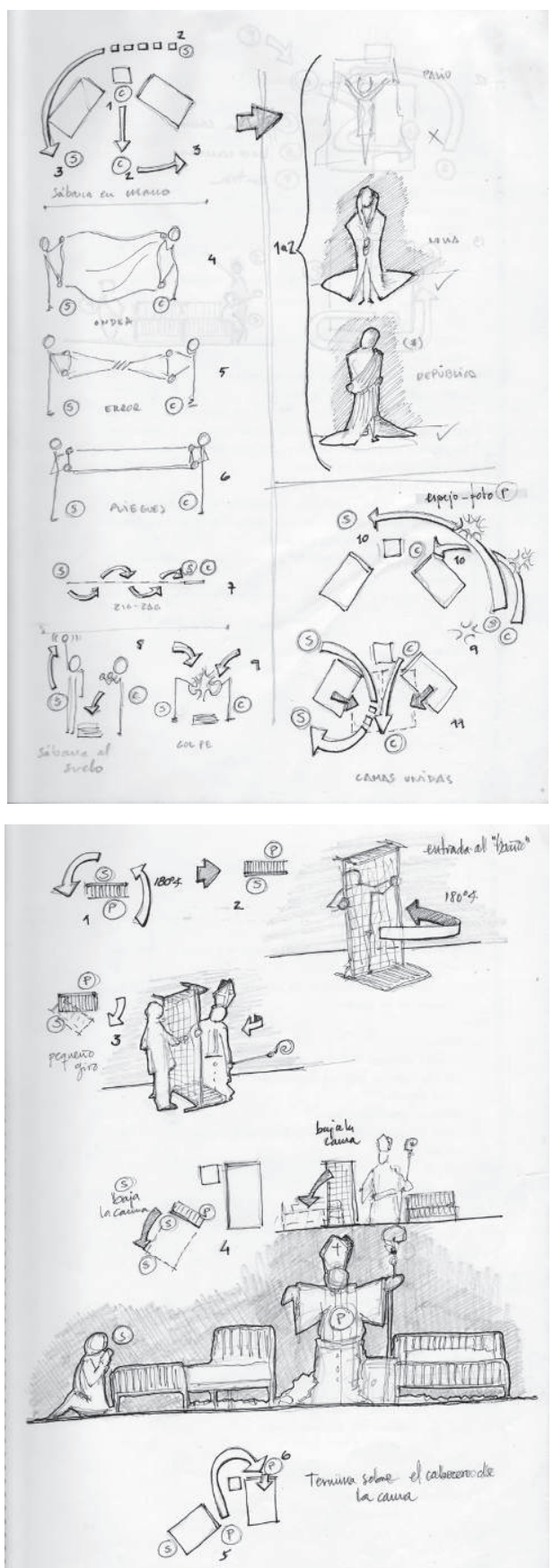
ANEXO II. Bocetos realizados para la obra Franco, el retorno por el escenógrafo José Luis Feliú Cervi.

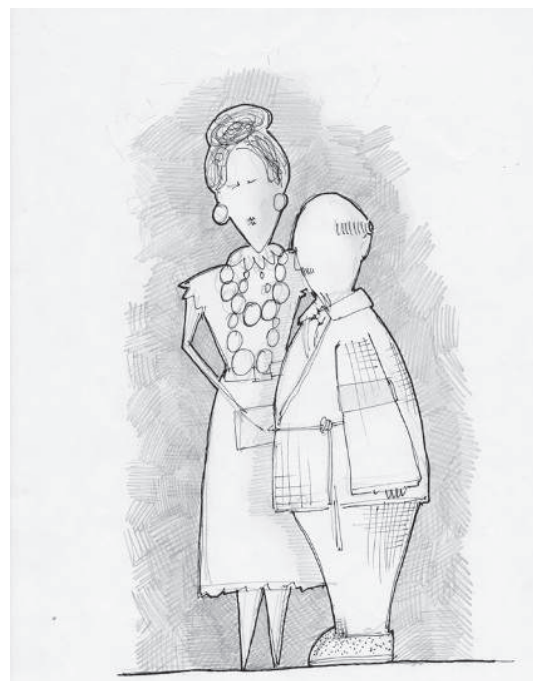

(c) José Luis Feliú Cervi.

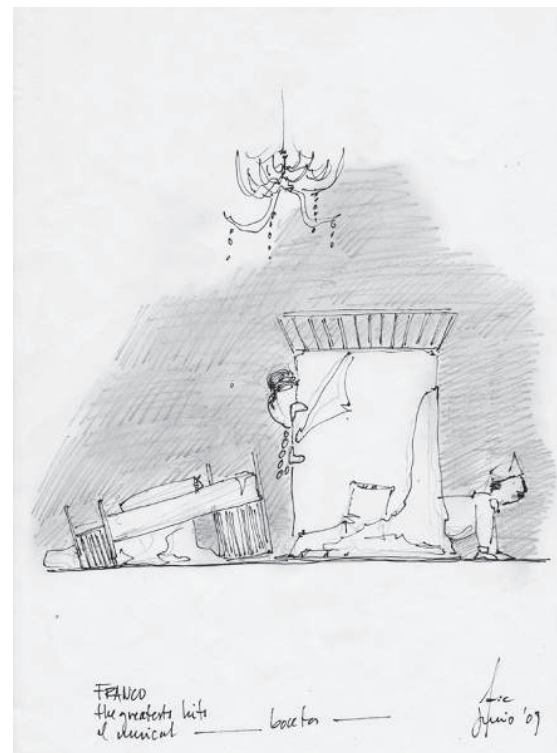

(C) José Luis Feliú Cervi.

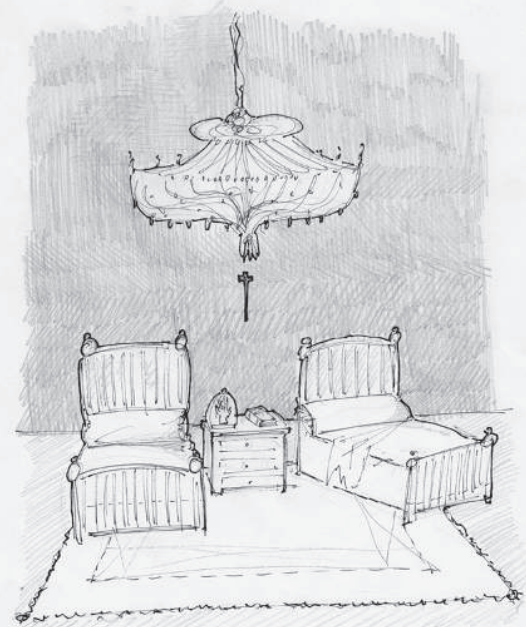

(C) José Luis Feliú Cervi.

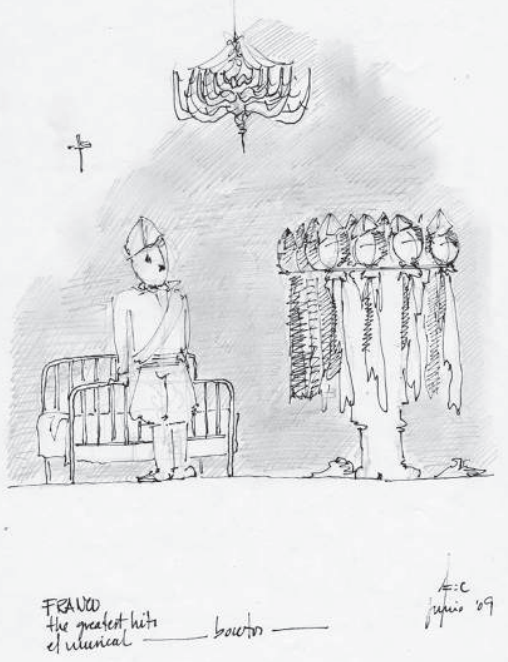

(C) José Luis Feliú Cervi. 

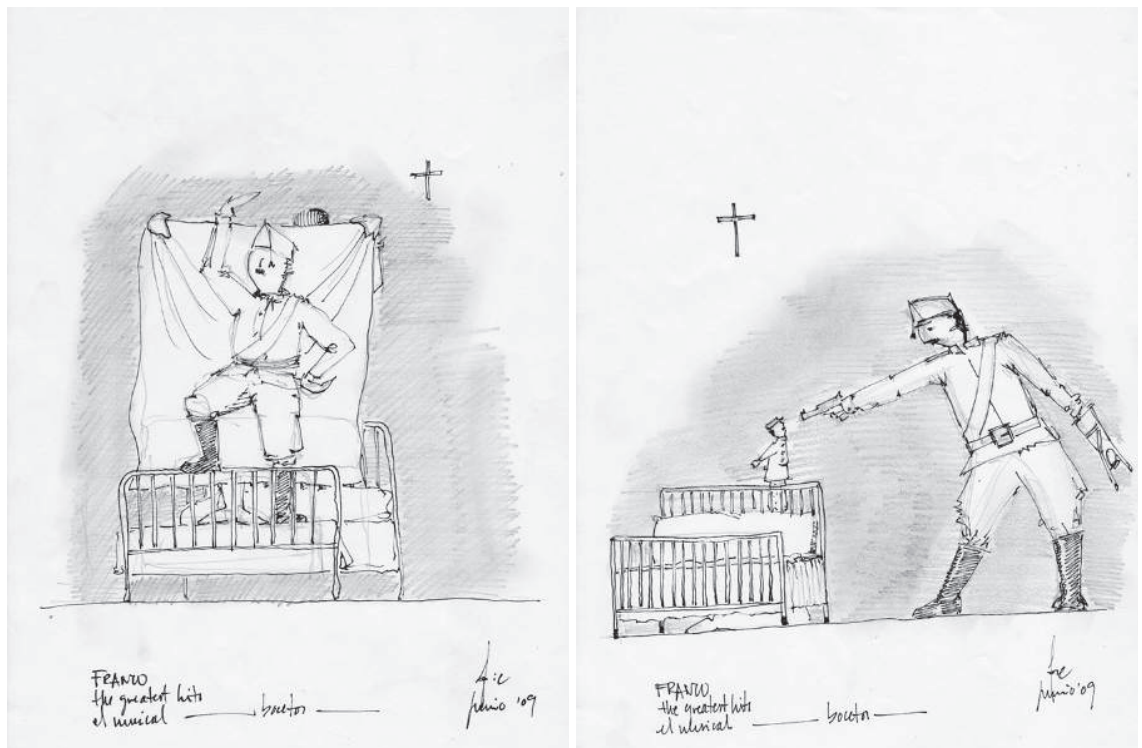

(C) José Luis Feliú Cervi.

(c) José Luis Feliú Cervi.
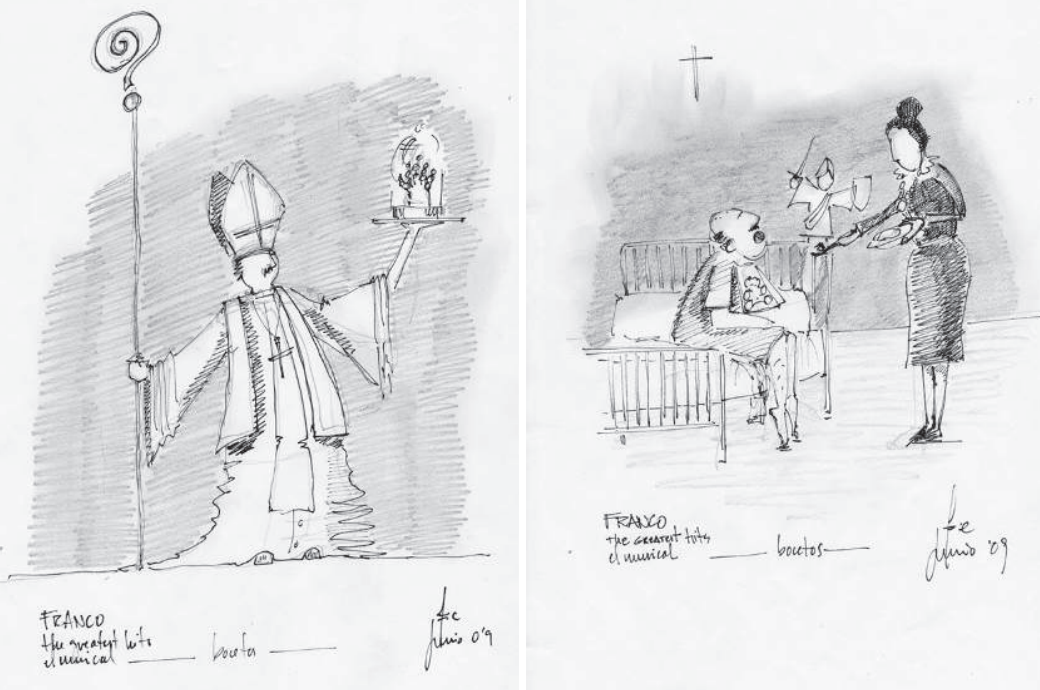

(C) José Luis Feliú Cervi.

C José Luis Feliú Cervi. 


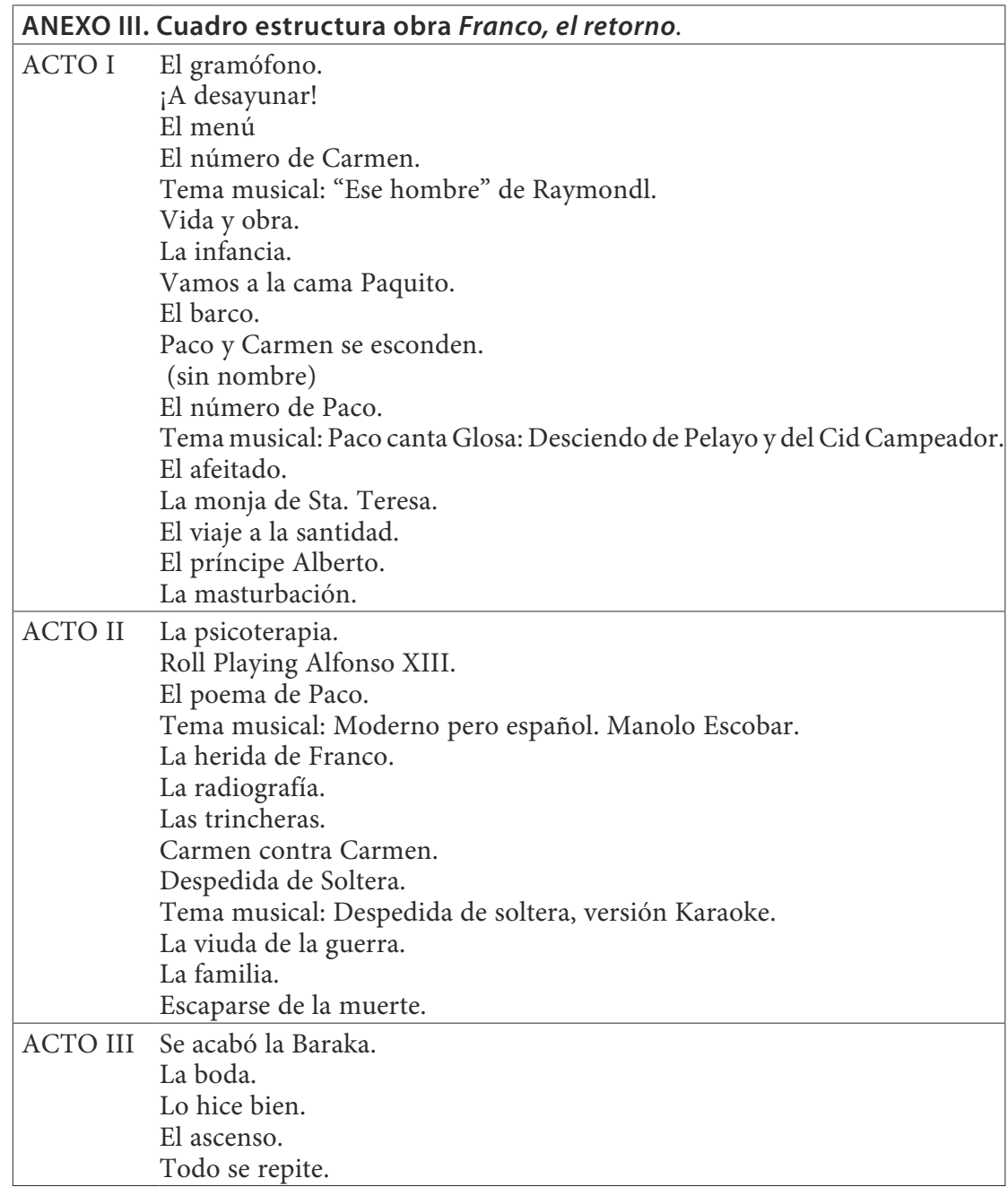

\section{ANEXO IV. Temas musicales de Franco, el retorno.}

Los temas musicales que se incorporaron a la obra fueron:

1. Ese hombre - Raymond.

2. Himno de España - Letra José María Pemán.

3. Glosa - Ricardo Cantalapiedra.

4. Moderno, pero español - Juan Gabriel García Escobar.

5. Despedida de soltera - Paquita Jerez.

6. La internacional.

7. A las barricadas. 